\title{
Review Article \\ Roles of p53 in Various Biological Aspects of Hematopoietic Stem Cells
}

\author{
Takenobu Nii, ${ }^{1}$ Tomotoshi Marumoto, ${ }^{1,2}$ and Kenzaburo Tani ${ }^{1,2}$ \\ ${ }^{1}$ Division of Molecular and Clinical Genetics, Medical Institute of Bioregulation, Kyushu University, 3-1-1, Maidashi, \\ Higashi-ku, Fukuoka 812-8582, Japan \\ ${ }^{2}$ Department of Advanced Molecular and Cell Therapy, Kyushu University Hospital, 3-1-1, Maidashi, \\ Higashi-ku, Fukuoka 812-8582, Japan \\ Correspondence should be addressed to Tomotoshi Marumoto, marumoto@sentan.med.kyushu-u.ac.jp
}

Received 22 March 2012; Accepted 14 May 2012

Academic Editor: Masamitsu Yamaguchi

Copyright ( $) 2012$ Takenobu Nii et al. This is an open access article distributed under the Creative Commons Attribution License, which permits unrestricted use, distribution, and reproduction in any medium, provided the original work is properly cited.

Hematopoietic stem cells (HSCs) have the capacity to self-renew as well as to differentiate into all blood cell types, and they can reconstitute hematopoiesis in recipients with bone marrow ablation. In addition, transplantation therapy using HSCs is widely performed for the treatment of various incurable diseases such as hematopoietic malignancies and congenital immunodeficiency disorders. For the safe and successful transplantation of HSCs, their genetic and epigenetic integrities need to be maintained properly. Therefore, understanding the molecular mechanisms that respond to various cellular stresses in HSCs is important. The tumor suppressor protein, p53, has been shown to play critical roles in maintenance of "cell integrity" under stress conditions by controlling its target genes that regulate cell cycle arrest, apoptosis, senescence, DNA repair, or changes in metabolism. In this paper, we summarize recent reports that describe various biological functions of HSCs and discuss the roles of p53 associated with them.

\section{Introduction}

Adult stem cells have recently attracted significant public attention, mostly because they can be a source of donor cells for replacing cells in transplantation therapies to treat various incurable diseases. In fact, hematopoietic stem cell (HSC) transplantation is now routinely performed to treat patients with hematopoietic malignancies and other disorders of the blood and immune systems. Thus, understanding the regulatory molecular networks that regulate stem cells is very important to develop new strategies of treatment for intractable diseases.

Among adult stem cell types, HSCs are the most extensively studied because they are relatively easy to obtain from both healthy and diseased persons, compared with isolation of adult stem cells from other tissues. HSCs are considered a very important cell population capable of self-renewal and differentiating into and supplying all blood cell types for life, whereas other hematopoietic cells such as hematopoietic progenitor cells (HPCs) and more differentiated cells undergo transient proliferation and die within a limited time period. Moreover, HSCs are of interest because of their plasticity to become cell types of other tissues $[1,2]$.

Under steady-state conditions, most HSCs are in quiescence, a period in the G0 phase of the cell cycle, and proliferate very slowly [3]. Thus, elucidation of the regulatory molecular mechanisms that execute self-renewal as well as entry into and exit from the quiescence of HSCs is essential to understand the biology of HSCs.

Additionally, understanding the molecular pathways of HSCs under the stress conditions of DNA damage is also critical to better deal with suppression of the hematopoietic system by irradiation or the cytotoxic effects of anticancer drugs including arsenic trioxide, anthracycline, cisplatin, and bleomycin that are currently used for the treatment of cancer.

Recent reports have suggested that HSCs are controlled by various cell cycle regulators such as $\mathrm{p} 53, \mathrm{p} 16^{\text {Ink4a }}$, and 
p19 Arf under both steady and stress conditions $[4,5]$. Among these regulators, p53 is extensively studied and well known as a major tumor suppressor involved in various critical cellular functions such as proliferation, cell cycle arrest, apoptosis, and DNA repair mechanisms $[6,7]$.

In this paper, we describe the molecular mechanisms for regulation of HSCs under both steady and stress conditions, and particularly the roles of p53 associated with HSC functions such as responses to cellular stresses, apoptosis, selfrenewal, senescence, and plasticity in addition to leukemia stem cells (LSCs).

\section{2. p53 as a DNA Damage Checkpoint Molecule}

Somatic cells, including immature tissue stem cells, constantly receive intrinsic and extrinsic DNA damage caused by various stresses. To maintain the genomic integrity of stem cells as well as tissue homeostasis, checkpoint mechanisms that activate DNA damage repair are crucial [8]. Among the types of DNA damage, double strand breaks (DSBs), which can be caused by current therapeutic approaches such as ionizing radiation and chemotherapy, are the most cytotoxic type of DNA lesion [9].

To minimize adverse effects caused by DSBs, cells rapidly activate the DNA damage checkpoint pathway after exposure to such stresses. Upon DNA damage, the sensor protein ataxia-telangiectasia mutated (ATM) is activated, which phosphorylates various downstream target proteins and induces the cell cycle checkpoint response [10, 11]. After sensing DNA damage, activated ATM directly phosphorylates the tumor suppressor p53 at serine 15 within its amino-terminal transactivation domain. ATM also activates CHK2, a serine threonine kinase, which phosphorylates p53 at threonine 18 and serine 20. MDM2, an E3 ubiquitin ligase that targets $\mathrm{p} 53$, is also phosphorylated by ATM. These phosphorylations that modify p53 and MDM2 directly or indirectly by ATM lead to transcriptional activation and stabilization of p53 [11]. Accumulation of p53 following low or repairable levels of DNA damage leads to activation of $\mathrm{p} 21^{\mathrm{Cip} 1}$ transcription, which inhibits cyclin-dependent kinases (CDKs) and induces a delay or arrest of the cell cycle $[12,13]$. During this delay or arrest of cell cycle progression induced by the checkpoint mechanism, cells have an opportunity to repair DNA damage. When DNA damage is high or irreparable, p53 induces transcription of proapoptotic genes such as BAX, NOXA, and PUMA that eliminate damaged cells $[14,15]$.

Tumor suppressors $\mathrm{p} 16^{\text {Ink4a }}$ and $\mathrm{p} 19^{\text {Arf }}$ are also CDK inhibitors. $\mathrm{p} 16^{\text {Ink4a }}$ and $\mathrm{p} 19^{\mathrm{Arf}}$ are distinct proteins translated from alternative reading frames of the same genomic locus called Cdkn2a. Whereas p16 $6^{\text {Ink4a }}$ binds to CDKs and prevents CDKs binding to cyclin $\mathrm{D}$, which results in the inhibition of phosphorylation of the retinoblastoma $(\mathrm{pRb})$ protein, $\mathrm{p} 19^{\mathrm{Arf}}$ binds to $\mathrm{Mdm} 2$ and inhibits its ubiquitin ligase activity toward p53, resulting in promotion of p53 stabilization. These genes are negatively regulated by $\mathrm{Bmi}-1$, which is strongly associated with HSC function as described below in the "p53 apoptosis pathway" section.

\section{3. p53 Signaling against Reactive-Oxygen- Species- (ROS-) Induced Stresses}

In living cells including HSCs, ROS such as superoxide anion $\left(\bullet \mathrm{O}_{2}^{-}\right)$, singlet oxygen $\left({ }^{1} \mathrm{O}_{2}\right)$, hydrogen peroxide $\left(\mathrm{H}_{2} \mathrm{O}_{2}\right)$, and hydroxyl radicals $(\bullet \mathrm{OH})$ are continuously generated owing to metabolic and other biochemical reactions as well as stresses caused by various extrinsic factors $[16,17]$. While ROS play physiological roles as secondary messengers in intracellular signaling cascades, they also induce oxidative stress that can cause damage to cellular structures, including lipids, membranes, proteins, and DNA, which is thought to contribute toward cancer development [16-18].

Ito et al. reported that $\mathrm{CD} 34^{-}$lineage ${ }^{-} \mathrm{Scal}^{+} \mathrm{c}^{-\mathrm{kit}^{+}}$ (CD34- LSK) HSCs can be separated into two fractions, cells with high and low ROS levels (ROS ${ }^{\text {high }}$ and ROS ${ }^{\text {low }}$ HSCs, resp.) and showed that ROS ${ }^{\text {low }}$ HSCs retain their long-term repopulating ability throughout serial transplantation assays, whereas this capacity decreases in serially transplanted ROS ${ }^{\text {high }}$ HSCs [19]. This decreased functional activity of ROS ${ }^{\text {high }}$ HSCs can be restored by treatment with the antioxidant $\mathrm{N}$-acetyl-L-cysteine (NAC), which acts as an antioxidative agent by scavenging ROS, indicating that the ROS level affects HSC functions [19]. Indeed, it has been reported that ROS is an inducer of cell cycling by disrupting the maintenance of HSC quiescence [20].

DNA damage induced by ROS results in p53 upregulation, but p53 expression has not been detected in ROS high HSCs and only slightly in ROS ${ }^{\text {low }}$ HSCs [21]. The reason for this low level of p53 in $\mathrm{ROS}^{\text {low }}$ HSCs is probably because a higher level of p53 decreases the intracellular ROS level to protect the genome from ROS-induced genomic damage by upregulating several antioxidant genes in $\mathrm{ROS}^{\text {low }}$ HSCs [22]. This role of p53 in downregulation of the ROS level in HSCs is enhanced by several molecules such as hypoxia inducible factor $1 \alpha$ (HIF- $1 \alpha$ ), an intrinsic transcription factor activated under a hypoxic condition [23]. HIF- $1 \alpha$ stabilizes p53 in a hypoxic area of the bone marrow in vivo [24]. Indeed, HIF$1 \alpha$ deficiency causes an increase in ROS levels and a decrease in HSC numbers during various stresses including a serial transplantation assay, suggesting that HSCs maintain their normal functions via downregulation of ROS by the HIF- $1 \alpha-$ p53 pathway [24].

Thus, p53 appears to play a central role in repressing ROS-induced stresses by upregulating antioxidant genes, which results in maintaining quiescence for the survival of HSCs.

\section{4. p53 Apoptosis Pathway}

As discussed in the above section, p53 functions in the survival and maintenance of HSCs, but it is also a critical regulator of apoptosis to eradicate HSCs in certain situations. It has been shown that the loss of Bmi-1 in HSCs results in impairment of HSC self-renewal owing to accumulation of p19 Arf, which causes p53-dependent apoptosis [25].

Similarly, conditional deletion of Cbp/p300-interacting transactivator with Glu/Asp-rich carboxy-terminal domain, 


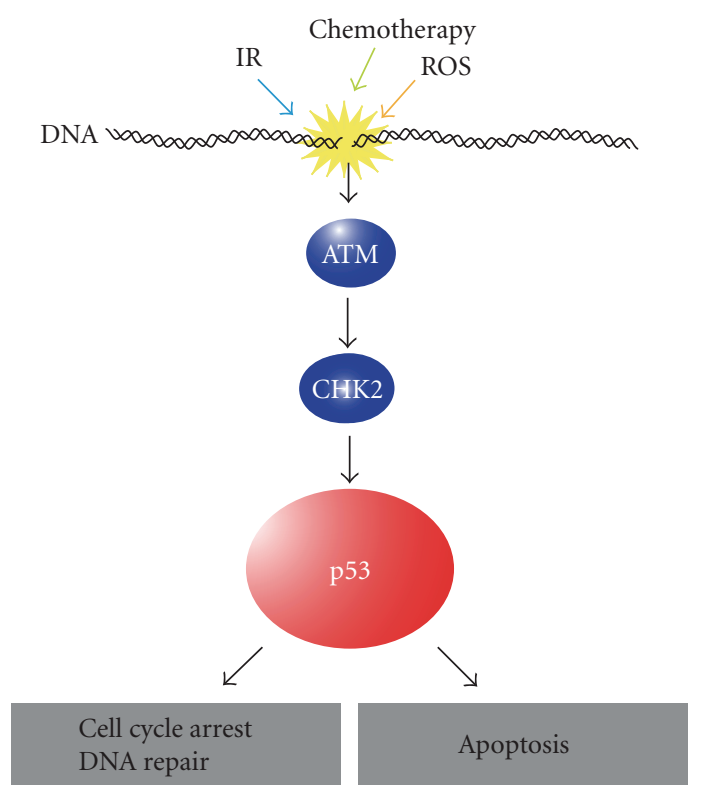

DNA damage

Low

High

Figure 1: Functions of p53 in response to DNA damage. Genomic stresses caused by ionizing radiation (IR), chemotherapy, and reactive oxygen species (ROS) activate DNA damage check point pathway, which leads to the activation of ATM and CHK2 and subsequent stabilization of p53. Then, stabilized p53 induces cell cycle arrest and DNA repair when DNA damage is moderate, whereas it activates apoptosis pathway when DNA damage is extensive.

2 (Cited2) that controls proliferation of mouse embryonic fibroblasts (MEFs) and highly expressed in long-term (LT)HSCs [26, 27], results in decreased HSC numbers [26]. This phenotype is rescued by additional deletion of p53, indicating that decreased HSC numbers in mice lacking Cited 2 are caused by p53-induced cell death [26]. Moreover, inactivation of F-box and WD-40 domain protein 7 (Fbxw7), a subunit of the SKP1-CUL1-F-box protein (SCF)-type ubiquitin ligase complex, leads to impairment of the HSC repopulating capacity and a reduced HSC pool owing to active cell cycling and p53-dependent apoptosis [28, 29].

As discussed above, p53 has two opposing roles in regulating the fate of HSCs, which might depend on the level of damage to HSCs and the effect on p53 activity in each situation (Figure 1).

\section{Roles of the Mdm2-p53 Pathway in HSCs}

To examine the significance of the Mdm2-p53 interaction in more detail, p53 mutant protein ( $553^{515 C}$ encoding p53R172P) that maintains the ability to induce senescence and cell cycle arrest, but not apoptosis, was analyzed in $\mathrm{Mdm} 2^{-/-} \mathrm{p} 53^{515 \mathrm{C} / 515 \mathrm{C}}$ mice [30]. Mdm2 $2^{-/-} \mathrm{p} 53^{515 \mathrm{C} / 515 \mathrm{C}}$ mice are born at normal Mendelian ratios but die by postnatal day 13 owing to hematopoietic failure [30]. Whereas the HSCs of Mdm2 $2^{-/-} \mathrm{p} 53^{515 \mathrm{C} / 515 \mathrm{C}}$ mice are normal in fetal livers at embryonic day (E)14.5, HSC numbers are significantly decreased in the bone marrow of E18.5 and postnatal mutant mice [30]. Moreover, ROS levels in fetal livers at E14.5 are low, but the bone marrow of E18.5 and postnatal $\mathrm{Mdm} 2^{-/-} \mathrm{p} 53^{515 \mathrm{C} / 515 \mathrm{C}}$ mice has higher ROS levels compared with that of $\mathrm{Mdm} 2^{+/-} \mathrm{p} 53^{515 \mathrm{C} / 515 \mathrm{C}}$ controls [30]. HSCs with a high ROS level in postnatal $\mathrm{Mdm} 2^{-/-} \mathrm{p} 53^{515 \mathrm{C} / 515 \mathrm{C}}$ mice show a reduced repopulating capacity, but this phenotype is rescued by NAC [30]. These results suggest that Mdm2 regulates appropriate hematopoiesis in postnatal mice by repressing ROS levels and regulating p53 activity.

\section{Function of p53 in HSC Self-Renewal and Quiescence}

It has been shown that hematopoiesis in $\mathrm{p} 53^{-/-}$mice is almost normal [31]. However, p53 is preferentially expressed in HSC populations compared with that in various myeloid progenitor cells including common myeloid progenitors (CMPs), granulocyte/monocyte progenitors (GMPs), and megakaryocyte/erythroid progenitors (MEPs) [4]. Lin ${ }^{-} \mathrm{Sca}-$ $1^{+}$cells are thought to contain HSC population in mice, and cells in quiescence are detected as PyroninY ${ }^{\text {low }}$ cells [4]. Liu et al. have performed PyroninY staining of Lin $^{-}$

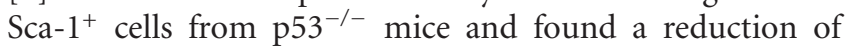
Pyronin $Y^{\text {low }}$ cells in the population, indicating that loss of p53 leads to decreased HSCs in quiescence [4]. HSCs in quiescence are also identified as CD34- lineage ${ }^{-} \mathrm{Sca}^{+} \mathrm{c}^{-} \mathrm{kit}^{+}$ side population cells (CD34- ${ }^{-}$LSK SP cells) based on their ability to efflux the fluorescent dye Hoechst 33342 [3, 32]. Liu et al. also found that CD34- LSK SP cells are decreased in adult bone marrow lacking $\mathrm{p} 53$, and proliferation of $\mathrm{p} 53^{-/-}$ CD34- LSK cells is increased significantly [4]. Furthermore, they identified growth factor independent-1 (Gfil) and Necdin as p53 target genes that maintain HSC quiescence by comparing the expression profiles of wild-type and p53null HSCs [4]. Therefore, p53 appears to play a role in promoting HSCs into quiescence, and HSCs tend to enter the cell cycle from quiescence in the absence of p53 (Figure 2). Consistent with this notion, it has been reported that loss of $\mathrm{p} 53$ function by the chemical p53 inhibitor, pifithrin $\beta$, promotes the proliferation of HSCs in vitro and in vivo [33].

HSCs lacking p53 are more successful at reconstituting bone marrow in a competitive repopulation assay, indicating that the repopulation capability of HSCs for the first transplantation of bone marrow is improved by inhibition of p53 [4, 34]. On the other hand, Chen et al. compared bone marrow reconstitution abilities between $\mathrm{SLAM}^{+} \mathrm{p} 53^{+/+}$ and $\mathrm{SLAM}^{+}$p $53^{-/-}$HSCs in a serial transplantation assay and found that lack of p53 reduces the repopulating ability of individual HSCs for serial transplantation, indicating that loss of p53 does not improve the long-term function of HSCs [35]. These results suggest that loss of p53 can improve selfrenewal and bone marrow repopulating capabilities over a short term but cannot maintain these capabilities of HSCs over a long term, probably owing to the reduced population of quiescent HSCs that have a long-term repopulating ability. 


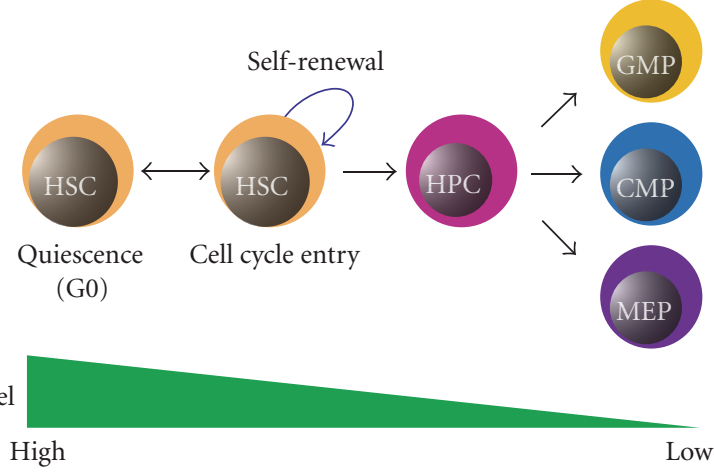

FIGURE 2: Regulation of quiescence and self-renewal in HSCs by p53. Maintenance of quiescence in HSCs needs proper expression of p53. Decrease in p53 expression promotes self-renewal and differentiation of HSCs.

HSC self-renewal is also affected by pathways activated by extracellular signaling molecules. Notch is a cell surface receptor that influences cell fate decisions such as cell differentiation, survival/apoptosis, and proliferation, which is activated by its ligand Jagged1 [36]. Activation of Notch leads to cleavage and release of the intracellular domain of Notch, which enters the nucleus and activates various transcription factors such as $\mathrm{C}$ promoter binding factor 1 (CBF1) [36]. Using transgenic Notch reporter mice, Duncan et al. reported that Notch pathway activation increases HSC self-renewal and decreases HSC differentiation in vivo [37]. However, Mancini et al. reported that HSC self-renewal does not require Jagged1-mediated Notch signaling, using conditional Jagged $1^{-/-}$mice [38]. Thus, the requirement of Notch signaling for HSC self-renewal is still controversial $[39,40]$. It should be noted that p53 is downregulated by Notch signaling [41], implying that an increase in HSC selfrenewal by the activation of Notch signaling might be partly mediated by the suppression of $\mathrm{p} 53$ function.

HSC self-renewal is also regulated by Wnt signaling, which is activated by binding of the extracellular "Wnt" ligand to the cell surface receptors of the Frizzled family. When Wnt binds to a Frizzled family receptor, $\beta$-catenin is stabilized by release from its inhibitory complex consisting of axin, glycogen synthase kinase-3 $\beta$ (GSK-3 $\beta$ ), and adenomatous polyposis coli (APC) (the APC/Axin/GSK-3 $\beta$ complex). The release of $\beta$-catenin from the APC/Axin/GSK$3 \beta$ complex allows the translocation of $\beta$-catenin to the nucleus to interact and activate $\mathrm{T}$ cell factor and lymphoid enhancer factor (TCF/LEF) transcription factors [42, 43]. Reya et al. elucidated that $\beta$-catenin overexpression or treatment with soluble Wnt3a in culture promotes HSC selfrenewal $[44,45]$. Furthermore, activation of Wnt signaling in HSCs increases the expression of Notch 1 and HoxB4, which strongly promotes HSC self-renewal $[44,45]$.

Additionally, microRNA-34 (miR-34) has been shown to bind to the untranslated region of $\beta$-catenin, leading to its downregulation [46]. Expression of miR-34 is induced by p53, and, therefore, p53 might downregulate Wnt signaling by miR-34-mediated inhibition of $\beta$-catenin, resulting in the suppression of self-renewal in HSCs.

Another essential signaling pathway involved in the regulation of stem cell self-renewal is Hedgehog signaling [47]. However, conditional knockout of Smoothened (Smo), an essential regulator of the Hedgehog pathway, does not show any dysfunction of HSCs, indicating that this pathway is dispensable for adult HSC self-renewal and other functions $[48,49]$.

The ability of HSCs to self-renew is also affected by the epigenetic status of chromatin structure regulated by components of the Polycomb complex, including Mel18, Rae28, and Bmi-1 [50]. Mice lacking Mel18 exhibit increased HoxB4 expression resulting in increased fetal HSC selfrenewal [51]. In contrast, Rae $28^{-/-}$mice exhibit decreased HSC self-renewal without affecting HoxB4 expression [25, 52]. Moreover, deficiency of Bmi-1 increases $\mathrm{p}^{16^{\text {Ink4a }}}$ and p19 Arf levels, resulting in an increased p53 level, which leads to the suppression of HSC self-renewal [25]. Thus, Polycomb genes appear to regulate HSC self-renewal by various mechanisms.

In addition, another epigenetic regulator of chromatin, Mi- $2 \beta$, a component of the chromatin remodeling nucleosome remodeling deacetylase (NuRD) complex, is involved in the regulation of HSC self-renewal [53]. Conditional inactivation of $\mathrm{Mi}-2 \beta$ in bone marrow promotes HSC differentiation and inhibits HSC self-renewal [53].

The significance of the p53 pathway in regulation of HSC self-renewal by Polycomb or NuRD complexes is poorly understood, except for the molecular mechanism responsible for the inhibition of HSC self-renewal in Bmi-1 $1^{-/-}$mice as described above.

CDK inhibitors involved in the G1 checkpoint of the cell cycle have also been shown to regulate HSC self-renewal [47]. Based on their sequence homology and specificity of action, CDK inhibitors are divided into two families: the Cip/Kip family including $221^{\mathrm{Cip} 1}, \mathrm{p} 27^{\mathrm{Kip} 1}$, and $\mathrm{p} 57^{\mathrm{Kip} 2}$, and the Ink4 family including $\mathrm{p} 16^{\text {Ink } 4 \mathrm{a}}, \mathrm{p} 15^{\text {Ink } 4 \mathrm{~b}}, \mathrm{p} 18^{\text {Ink } 4 \mathrm{c}}$, and p19 ${ }^{\text {Ink4d }}[54]$.

Among the Cip/Kip family, p $21^{\mathrm{Cip} 1}$ is upregulated by p53 in response to DNA damage, which induces cell cycle arrest by inhibiting CDKs as discussed above in Section 2 [12, $13,55]$. Cheng et al. showed that $\mathrm{p} 21^{\mathrm{Cip} 1}$ plays an essential role in HSC quiescence and self-renewal by analyzing cells from B6/129 mixed background mice [56]. However, van Os et al. showed that HSC self-renewal is not impaired by analyzing pure B6 mice lacking p $21^{\mathrm{Cip} 1}$ under normal conditions, whereas a deficiency of $\mathrm{p} 21^{\mathrm{Cip} 1}$ decreases selfrenewal in a competitive repopulation assay only when HSCs undergo irradiation stress [57]. The discrepancy regarding the importance of $\mathrm{p} 21^{\mathrm{Cip} 1}$ for HSC self-renewal in a steady state between these two studies might be due to the difference in the genetic background of the mice used for analysis.

p57 Kip2 , another member of the Cip/Kip family, has been shown to be predominantly expressed in the LT-HSC population $[58,59]$. Matsumoto et al. generated conditional p5 $7^{\text {Kip2 }}$-knockout mice and showed that $\mathrm{p} 57^{\mathrm{Kip} 2}$ deficiency decreases HSC quiescence and self-renewal. In addition, loss of $\mathrm{p} 57^{\mathrm{Kip} 2}$ results in upregulation of $\mathrm{p} 53$, leading to 
activation of the p53-dependent apoptosis pathway in HSCs, suggesting that $\mathrm{p} 57^{\mathrm{Kip} 2}$ is required for the maintenance of both quiescence and self-renewal of the HSC pool in adult mice [59].

On the other hand, Zou et al. isolated HSCs from p57 Kip2-/- embryos, which are neonatal lethal $[60,61]$, and showed that loss of $\mathrm{p} 57^{\mathrm{Kip} 2}$ results in a substantial reduction in the repopulating capacity of embryonic HSCs, but does not affect the number of HSCs in quiescence [58]. Moreover, deletion of $\mathrm{p} 57^{\mathrm{Kip} 2}$ results in upregulation of $\mathrm{p} 27^{\mathrm{Kip} 1}$ in embryonic HSCs, and loss of both $\mathrm{p} 57^{\mathrm{Kip} 2}$ and $\mathrm{p} 27^{\mathrm{Kip} 1}$ impairs maintenance of the quiescence and self-renewal of HSCs, which is more obvious compared with those of HSCs in mice lacking $\mathrm{p} 57^{\mathrm{Kip} 2}$ alone, suggesting that $\mathrm{p} 57^{\mathrm{Kip} 2}$ and p27 ${ }^{\text {Kipl }}$ cooperate to maintain embryonic HSC quiescence and self-renewal, and $\mathrm{p} 27^{\mathrm{Kip} 1}$ can partially compensate for the function of $\mathrm{p} 57^{\mathrm{Kip} 2}$ [58]. The slight difference regarding the roles of $\mathrm{p} 57^{\mathrm{Kip} 2}$ in the maintenance of quiescence in HSCs might be due to their origin.

Furthermore, loss of $\mathrm{p} 27^{\mathrm{Kip} 1}$ alone in adult mice does not affect HSC self-renewal and quiescence, suggesting that $\mathrm{p} 27^{\mathrm{Kip} 1}$ is not essential for HSC function under normal conditions $[58,62]$.

It has been shown that loss of other CDK inhibitors, such as $\mathrm{p} 16^{\text {Ink4a }}, \mathrm{p} 15^{\text {Ink4b }}$, or $\mathrm{p} 18^{\text {Ink4c }}$ in the Ink4 family, results in an increase in HSC self-renewal, although the function of $\mathrm{p} 19^{\text {Ink4d }}$ for HSC self-renewal remains unknown $[5,63-65]$, indicating that they are independent negative regulators of HSC self-renewal. Interestingly, mice with triple knockout of p16 ${ }^{\text {Ink4a }}, \mathrm{p} 19^{\text {Arf }}$, and p53 show a remarkable increase in HSC self-renewal. p19 $9^{\text {Arf }}$ binds to Mdm2 and inhibits the degradation of $\mathrm{p} 53$, thus $\mathrm{p} 16^{\text {Ink4a }}$ and the $\mathrm{p} 19^{\text {Arf }}$ p53 pathway synergistically downregulate the self-renewal capacity of HSCs [5].

Interestingly, among CDK inhibitors, loss of Cip/Kip family members such as $\mathrm{p} 21^{\mathrm{Cip} 1}, \mathrm{p} 27^{\mathrm{Kip} 1}$, and $\mathrm{p} 57^{\mathrm{Kip} 2}$ results in reduced HSC self-renewal, whereas loss of Ink4 family members such as $\mathrm{p} 16^{\text {Ink4a }}, \mathrm{p} 15^{\text {Ink4b }}$, and $\mathrm{p} 18^{\text {Ink } 4 \mathrm{c}}$ leads to increased HSC self-renewal $[5,56-59,62,65,66]$. Although this difference regarding the roles of the two families in HSC self-renewal is interesting, its significance remains unknown.

\section{Cellular Senescence, Organismal Aging, and p53 in HSCs}

Although senescence and quiescence can be considered as analogous phenomena, they are different from each other. While senescence is programmed and essentially irreversible, quiescence is dependent upon environmental stimuli and is reversible [67]. Both are initiated by failure to progress through the G1 phase. Campisi have revealed that cellular senescence plays a critical role in tumor suppression in vivo [68].

Mutation and shortening of telomeres, a region of repeated nucleotide sequences at both ends of a chromosome, are important factors in cellular senescence $[69,70]$. During DNA replication, DNA polymerase that synthesizes new DNA cannot completely replicate the telomere.
Telomerase extends the telomere region to prevent telomere shortening. Telomerase consists of two essential components: a telomerase RNA component (Terc) and telomerase reverse transcriptase (Tert) [71]. Both components have been shown to be essential for telomerase activity. $\mathrm{Terc}^{-/-}$mice exhibit significantly shortened telomeres in HSCs, reduced regenerative capacity, and impaired hematopoiesis [71, 72]. These hematopoietic failures in $\mathrm{Terc}^{-/-}$mice are caused by activation of p53-dependent senescence in response to DNA damage caused by telomere shortening $[71,73,74]$.

Mice expressing a truncated mutant of p53 lacking the first six exons ( $553^{+/ m}$ mice) show hyperactive $\mathrm{p} 53$ activity, compared with that of wild-type mice, and exhibit an organismal aging phenotype such as reduced longevity, osteoporosis, generalized organ atrophy, and diminished stress tolerance [75]. Moreover, in older mice (18-20

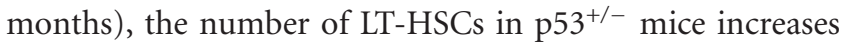
compared with that in $\mathrm{p}^{2} 3^{+/+}$mice, and the number of

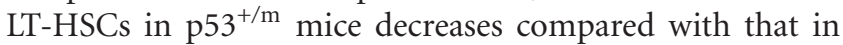
$\mathrm{p} 53^{+/+}$mice, suggesting that an increase or activation of $\mathrm{p} 53$ leads to cellular senescence and organismal aging in HSCs [76], although the contribution of cellular senescence to organismal aging is still controversial [77].

\section{LSCs and p53}

Cancer stem cells (CSCs) are defined as cells that can selfrenew, produce various types of progeny cells with more differentiated characteristics, and have a strong ability to drive continued expansion of malignant cells [78-80]. These properties of CSCs have similarities with those that define normal tissue stem cells.

CSCs in leukemia are called LSCs [81], and LSCs in acute myeloid leukemia (AML) have been well characterized [82-84]. Bonnet and Dick have shown that a CD34 $\mathrm{CD} 38^{-}$rare subpopulation of leukemic cells is capable of initiating leukemia in nonobese-diabetic severe combined immunodeficient (NOD-SCID) mice, which is histologically very similar to the original AML [82]. Thus, LSCs share phenotypical similarities with normal HSCs, such as self-renewal and expression of the surface marker, CD34, although there are some differences such as the expression of the interleukin-3 receptor $\alpha(\mathrm{IL}-3 \mathrm{R} \alpha)[85,86]$.

The proliferation of LSCs and normal HSCs/HPCs has been shown to be regulated by the Polycomb group (PcG) gene Bmi-1 [87]. Lessard and Sauvageau have shown that Hoxa9 and Meisla (AML-associated oncogenes) transduced fetal liver cells can form AML in sublethally irradiated syngeneic mice regardless of the presence of Bmi-1. However, Hoxa9-Meisla transduced leukemic bone marrow cells lacking Bmi-1 cannot induce AML in secondary recipient mice, whereas control Hoxa9-Meisla transduced leukemic bone marrow cells having Bmi- 1 can induce AML, suggesting that Bmi-1 is important for LSCs to retain their capacity to initiate leukemias in vivo [87].

Additionally, in human acute promyelocytic leukemia (APL), expression of PML-RAR, a fusion type of oncogene, induces deacetylation and degradation of p53, leading to 


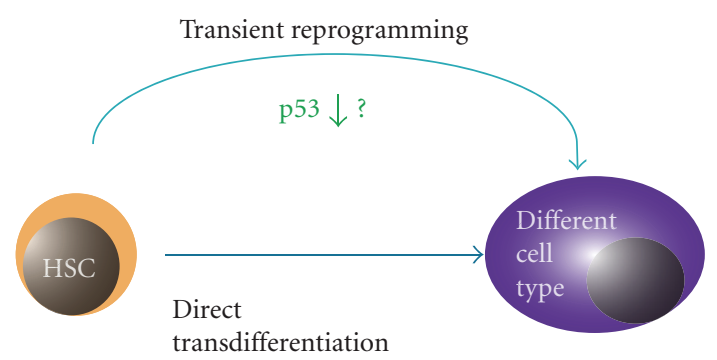

Figure 3: Possible mechanisms of HSC transdifferentiation. HSCs might directly transdifferentiate into another cell type (lower arrow) or through transient reprogramming in certain conditions. Loss of p53 might promote transient reprogramming for HSC transdifferentiation.

repressed p53 transcriptional activity and allowing APL cells to overcome p53-mediated stress responses that induce their eradication [88]. Interestingly, Viale et al. reported that PMLRAR expression in HSCs causes DNA damage and results in upregulation of p21 [89], leading to the cell cycle restriction and repair of damaged DNA [89]. The authors also suggested that the presence of moderate DNA damage, caused by oncogenes, and DNA repair activity enhanced by upregulated p21 increase the chance of mutagenesis in HSCs [89]. Thus, p21 and the associated DNA repair mechanisms appear to play critical roles in initiation and maintenance of LSCs in APL and may be appropriate targets for the treatment of this disease.

Interestingly, the behavior of LSCs is suggested to be associated with the drug resistance of certain types of leukemia [90]. For instance, CD $34^{+}$LSCs in chronic myelogenous leukemia (CML) in the G0 phase of the cell cycle (quiescence) are highly insensitive to Imatinib methylate (Gleevec or Glivec; previously known as STI-571 or CGP57148B) that targets the tyrosine kinase activity of BCR-ABL oncogene, whereas most dividing cells are eradicated by the drug [91-102]. Therefore, reduction of an LSC population in quiescence by the inhibition of senescence-inducing proteins such as p53 might be an effective strategy to negate the drug resistance of LSCs $[103,104]$.

\section{Plasticity of HSCs}

The notion that tissue-specific stem cells can only differentiate into cells of their tissue origin has been widely accepted, but several recent reports indicate that tissue-specific stem cells, including HSCs, can differentiate into cell types of various lineages $[105,106]$. In 1998, Ferrari et al. described that unfractionated normal bone marrow cells transplanted into SCID mice with chemically induced muscle damage can contribute to muscle regeneration [107]. Similarly, Bittner et al. have performed transplantation of normal bone marrow cells into mice with experimental muscular dystrophy, a genetic disease with progressive weakness of skeletal muscles, and found that bone-marrow-derived cells are recruited to skeletal and cardiac muscles and differentiate into muscle cells, although the bone marrow subpopulation that engrafted in muscles was not clearly shown [108]. Orlic et al. reported that transplanted lineage-negative bone marrow cells expressing $\mathrm{c}-\mathrm{kit}\left(\mathrm{Lin}^{-} \mathrm{c}^{-\mathrm{kit}^{+}}\right.$cells) can contribute to myocardial regeneration in a mouse model of experimental myocardial infarction [109]. Other groups also indicate that bone marrow contains stem cells capable of differentiating into functional muscle cells $[1,2]$.

Bone marrow cells have also been suggested to contribute to the regeneration of liver cells. Lagasse et al. injected c-kit ${ }^{\text {high }}$ Thy ${ }^{\text {low }}$ Lin $^{-}$Sca- $1^{+}$(KTLS) HSCs intravenously into lethally irradiated mice with progressive liver failure and renal tubular damage owing to a lack of fumarylacetoacetate hydrolase (FAH) and found that KTLS HSCs can give rise to functional hepatocytes [110]. Such differentiation of a bone marrow population enriched with HSCs into mature hepatocytes in rodents has also been described by other studies $[111,112]$. Moreover, the differentiation of bonemarrow-derived cells into mature hepatocytes has also been found in humans $[113,114]$.

Lin et al. showed that a small population of circulating endothelial progenitor cells (CEPs) derived from bone marrows exist in peripheral blood and contribute to postnatal neovascularization [115]. Asahara et al. performed transplantation of bone marrow mononuclear cells derived from transgenic mice expressing $\beta$-galactosidase (lacZ) driven by the endothelial cell-specific promoter (Flk1/LZ or Tie2/LZ) into lethally irradiated immunodeficient mice and examined neovascularization under various conditions by observing lacZ-positive cells. They concluded that bonemarrow-derived CEPs incorporate into and contribute to postnatal physiological and pathological neovascularization [116]. Krause et al. reported that adult bone marrow cells can differentiate into epithelial cells in the liver, lung, gastrointestinal tract, and skin [117].

As discussed above, although the plasticity of HSCs or cells in bone marrow is intriguing, the molecular mechanisms responsible for the transdifferentiation of HSCs or cells in bone marrow into cells of other tissue lineages remain unknown. One possibility is that the transdifferentiation of HSCs might occur by direct conversion of the epigenetic status of genes. Another possibility is that it might be induced by transient reprogramming of the genome (Figure 3 ). It has recently been shown that suppression of the p53-p21 pathway promotes the reprogramming efficiency of somatic cells by transfection of reprogramming factors such as Oct3/4 (also known as Pou5f1), Sox2, Klf4, and c-Myc in mice [118]. Thus, inhibition of p53 might facilitate the plasticity of HSCs or bone marrow cells.

\section{Conclusions}

In this paper, we focused on recent advances in research regarding the roles of p53 associated with the regulation of HSCs and LSCs. It is surprising that one molecule plays roles in the various aspects of important normal cells as well as malignant cells (Figure 4). The importance of HSCs for various transplantation therapies of incurable diseases such as leukemias is obvious, and continuous efforts to elucidate 


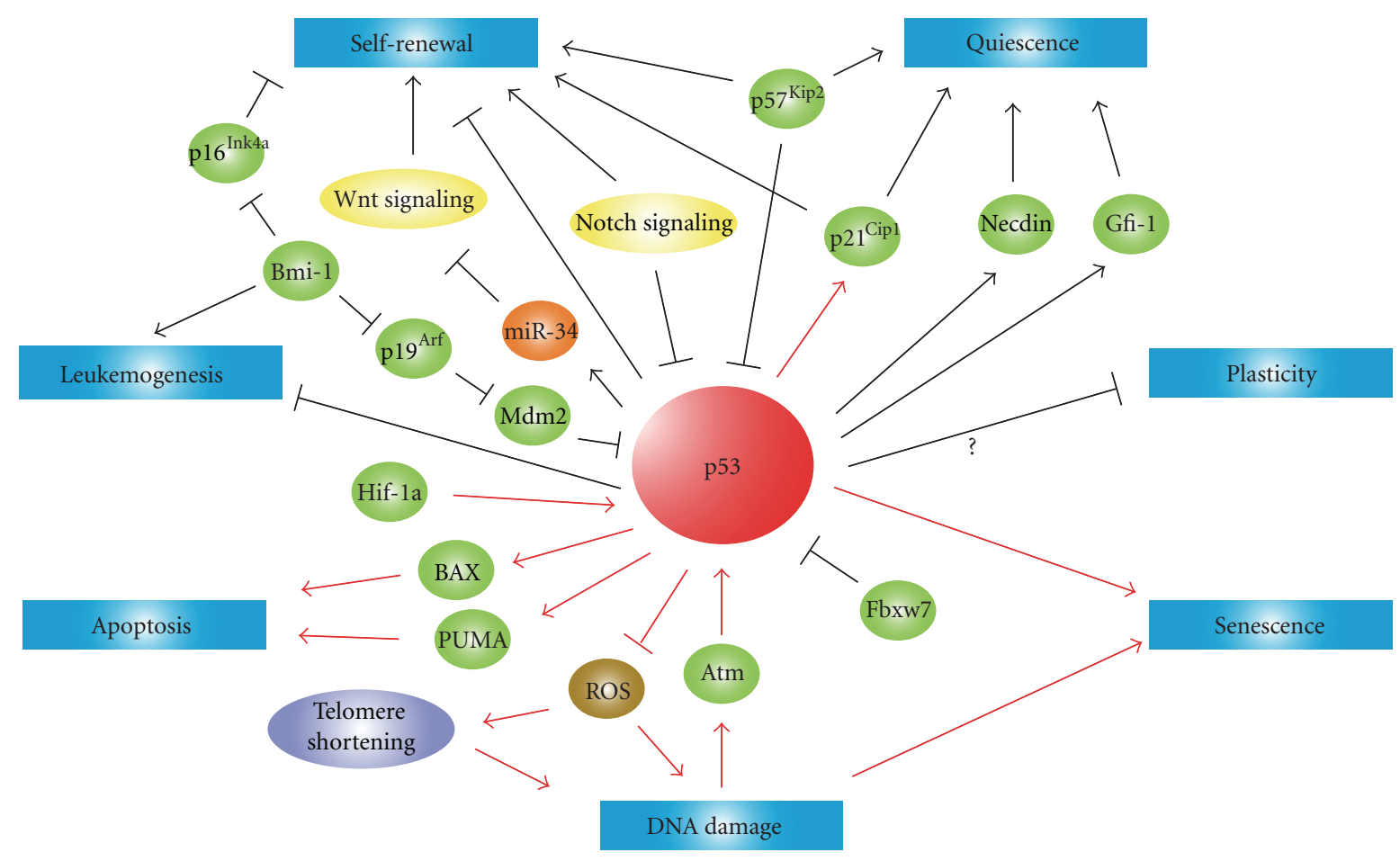

FIGURE 4: Schematic diagram of p53 roles in HSCs. p53 is involved in the control of response to DNA damage, self-renewal, quiescence, apoptosis, senescence, leukemogenesis, and plasticity in HSCs. Lines with an arrowhead indicate promotion and lines with a bar inhibition in steady state (black) or stress conditions (red).

the precise functions of p53 as a main regulator of HSCs will remain crucial and provide an insight into new strategies for treating various disorders.

\section{Acknowledgments}

The authors thank Michiko Ushijima for her administrative assistance and the members of Kenzaburo Tani's laboratory for providing constructive criticism and discussions. This work was supported by a grant from the Project for Realization of Regenerative Medicine (K. Tani, 08008010) and KAKENHI (T. Marumoto, 23590465) from the Ministry of Education, Culture, Sports, Science and Technology (MEXT), Japan.

\section{References}

[1] E. Gussoni, Y. Soneoka, C. D. Strickland et al., "Dystrophin expression in the mdx mouse restored by stem cell transplantation," Nature, vol. 401, no. 6751, pp. 390-394, 1999.

[2] K. A. Jackson, S. M. Majka, H. Wang et al., "Regeneration of ischemic cardiac muscle and vascular endothelium by adult stem cells," Journal of Clinical Investigation, vol. 107, no. 11, pp. 1395-1402, 2001.

[3] F. Arai, A. Hirao, M. Ohmura et al., "Tie2/angiopoietin-1 signaling regulates hematopoietic stem cell quiescence in the bone marrow niche," Cell, vol. 118, no. 2, pp. 149-161, 2004.

[4] Y. Liu, S. E. Elf, Y. Miyata et al., "p53 regulates hematopoietic stem cell quiescence," Cell Stem Cell, vol. 4, no. 1, pp. 37-48, 2009 .
[5] O. O. Akala, I. K. Park, D. Qian, M. Pihalja, M. W. Becker, and M. F. Clarke, "Long-term haematopoietic reconstitution by Trp $53^{-/-} \mathrm{p} 16^{\text {Ink4a-I- }} \mathrm{p} 19^{\text {Arf }-/-}$ multipotent progenitors," Nature, vol. 453, no. 7192, pp. 228-232, 2008.

[6] J. S. Fridman and S. W. Lowe, "Control of apoptosis by p53," Oncogene, vol. 22, no. 56, pp. 9030-9040, 2003.

[7] T. Marumoto, A. Tashiro, D. Friedmann-Morvinski et al., "Development of a novel mouse glioma model using lentiviral vectors," Nature Medicine, vol. 15, no. 1, pp. 110-116, 2009.

[8] D. B. Lombard, K. F. Chua, R. Mostoslavsky, S. Franco, M. Gostissa, and F. W. Alt, "DNA repair, genome stability, and aging," Cell, vol. 120, no. 4, pp. 497-512, 2005.

[9] M. Mohrin, E. Bourke, D. Alexander et al., "Hematopoietic stem cell quiescence promotes error-prone DNA repair and mutagenesis," Cell Stem Cell, vol. 7, no. 2, pp. 174-185, 2010.

[10] A. Poehlmann and A. Roessner, "Importance of DNA damage checkpoints in the pathogenesis of human cancers," Pathology Research and Practice, vol. 206, no. 9, pp. 591-601, 2010.

[11] M. B. Kastan and J. Bartek, "Cell-cycle checkpoints and cancer," Nature, vol. 432, no. 7015, pp. 316-323, 2004.

[12] G. M. Wahl and A. M. Carr, "The evolution of diverse biological responses to DNA damage: insights from yeast and p53," Nature Cell Biology, vol. 3, no. 12, pp. E277-E286, 2001.

[13] M. B. Kastan and D. S. Lim, "The many substrates and functions of ATM," Nature Reviews Molecular Cell Biology, vol. 1, no. 3, pp. 179-186, 2000.

[14] D. Tang, M. T. Lotze, R. Kang, and H. J. Zeh, "Apoptosis promotes early tumorigenesis," Oncogene, vol. 30, no. 16, pp. 1851-1854, 2011. 
[15] C. Ploner, R. Kofler, and A. Villunger, "Noxa: at the tip of the balance between life and death," Oncogene, vol. 27, no. 1, pp. S84-S92, 2008.

[16] S. Loft and H. E. Poulsen, "Cancer risk and oxidative DNA damage in man," Journal of Molecular Medicine, vol. 74, no. 6, pp. 297-312, 1996.

[17] H. Pelicano, D. Carney, and P. Huang, "ROS stress in cancer cells and therapeutic implications," Drug Resistance Updates, vol. 7, no. 2, pp. 97-110, 2004.

[18] M. Valko, C. J. Rhodes, J. Moncol, M. Izakovic, and M. Mazur, "Free radicals, metals and antioxidants in oxidative stress-induced cancer," Chemico-Biological Interactions, vol. 160, no. 1, pp. 1-40, 2006.

[19] K. Ito, A. Hirao, F. Arai et al., "Reactive oxygen species act through p38 MAPK to limit the lifespan of hematopoietic stem cells," Nature Medicine, vol. 12, no. 4, pp. 446-451, 2006.

[20] K. Miyamoto, K. Y. Araki, K. Naka et al., "Foxo3a is essential for maintenance of the hematopoietic stem cell pool," Cell Stem Cell, vol. 1, no. 1, pp. 101-112, 2007.

[21] Y. Y. Jang and S. J. Sharkis, "A low level of reactive oxygen species selects for primitive hematopoietic stem cells that may reside in the low-oxygenic niche," Blood, vol. 110, no. 8, pp. 3056-3063, 2007.

[22] A. A. Sablina, A. V. Budanov, G. V. Ilyinskaya, L. S. Agapova, J. E. Kravchenko, and P. M. Chumakov, "The antioxidant function of the p53 tumor suppressor," Nature Medicine, vol. 11, no. 12, pp. 1306-1313, 2005.

[23] V. Vukovic, H. K. Haugland, T. Nicklee, A. J. Morrison, and D. W. Hedley, "Hypoxia-inducible factor- $1 \alpha$ is an intrinsic marker for hypoxia in cervical cancer xenografts," Cancer Research, vol. 61, no. 20, pp. 7394-7398, 2001.

[24] K. Takubo, N. Goda, W. Yamada et al., "Regulation of the HIF- $1 \alpha$ level is essential for hematopoietic stem cells," Cell Stem Cell, vol. 7, no. 3, pp. 391-402, 2010.

[25] I. K. Park, D. Qian, M. Kiel et al., "Bmi-1 is required for maintenance of adult self-renewing haematopoietic stem cells," Nature, vol. 423, no. 6937, pp. 302-305, 2003.

[26] K. R. Kranc, H. Schepers, N. P. Rodrigues et al., "Cited2 is an essential regulator of adult hematopoietic stem cells," Cell Stem Cell, vol. 5, no. 6, pp. 659-665, 2009.

[27] K. R. Kranc, S. D. Bamforth, J. Bragança, C. Norbury, M. Van Lohuizen, and S. Bhattacharya, "Transcriptional coactivator Cited2 induces Bmil and Mel18 and controls fibroblast proliferation via Ink4a/ARF," Molecular and Cellular Biology, vol. 23, no. 21, pp. 7658-7666, 2003.

[28] K. I. Nakayama and K. Nakayama, Regulation of the Cell Cycle by SCF-Type Ubiquitin Ligases, Elsevier, 2005.

[29] S. Matsuoka, Y. Oike, I. Onoyama et al., "Fbxw7 acts as a critical fail-safe against premature loss of hematopoietic stem cells and development of T-ALL," Genes and Development, vol. 22, no. 8, pp. 986-991, 2008.

[30] H. A. Abbas, D. R. MacCio, S. Coskun et al., "Mdm2 is required for survival of hematopoietic stem cells/progenitors via dampening of ROS-induced p53 activity," Cell Stem Cell, vol. 7, no. 5, pp. 606-617, 2010.

[31] J. Lotem and L. Sachs, "Hematopoietic cells from mice deficient in wild-type p53 are more resistant to induction of apoptosis by some agents," Blood, vol. 82, no. 4, pp. 1092 1096, 1993.

[32] A. Terunuma, K. L. Jackson, V. Kapoor, W. G. Telford, and J. C. Vogel, "Side population keratinocytes resembling bone marrow side population stem cells are distinct from labelretaining keratinocyte stem cells," Journal of Investigative Dermatology, vol. 121, no. 5, pp. 1095-1103, 2003.
[33] K. I. Leonova, J. Shneyder, M. P. Antoch et al., "A small molecule inhibitor of p53 stimulates amplification of hematopoietic stem cells but does not promote tumor development in mice," Cell Cycle, vol. 9, no. 7, pp. 1434-1443, 2010.

[34] M. TeKippe, D. E. Harrison, and J. Chen, "Expansion of hematopoietic stem cell phenotype and activity in Trp53-null mice," Experimental Hematology, vol. 31, no. 6, pp. 521-527, 2003.

[35] J. Chen, F. M. Ellison, K. Keyvanfar et al., "Enrichment of hematopoietic stem cells with SLAM and LSK markers for the detection of hematopoietic stem cell function in normal and Trp53 null mice," Experimental Hematology, vol. 36, no. 10, pp. 1236-1243, 2008.

[36] S. Artavanis-Tsakonas, K. Matsuno, and M. E. Fortini, "Notch signaling," Science, vol. 268, no. 5208, pp. 225-232, 1995.

[37] A. W. Duncan, F. M. Rattis, L. N. DiMascio et al., "Integration of Notch and Wnt signaling in hematopoietic stem cell maintenance," Nature Immunology, vol. 6, no. 3, pp. 314-322, 2005.

[38] S. J. C. Mancini, N. Mantei, A. Dumortier, U. Suter, H. R. MacDonald, and F. Radtke, "Jagged1-dependent Notch signaling is dispensable for hematopoietic stem cell selfrenewal and differentiation," Blood, vol. 105, no. 6, pp. 2340 2342, 2005

[39] K. V. Pajcini, N. A. Speck, and W. S. Pear, "Notch signaling in mammalian hematopoietic stem cells," Leukemia, vol. 25, pp. 1525-1532, 2011.

[40] T. Suzuki and S. Chiba, "Notch signaling in hematopoietic stem cells," International Journal of Hematology, vol. 82, no. 4, pp. 285-294, 2005.

[41] L. J. Beverly, D. W. Felsher, and A. J. Capobianco, "Suppression of $\mathrm{p} 53$ by Notch in lymphomagenesis: implications for initiation and regression," Cancer Research, vol. 65, no. 16, pp. 7159-7168, 2005.

[42] K. M. Cadigan and R. Nusse, "Wnt signaling: a common theme in animal development," Genes and Development, vol. 11, no. 24, pp. 3286-3305, 1997.

[43] K. Willert and R. Nusse, " $\beta$-catenin: a key mediator of Wnt signaling," Current Opinion in Genetics and Development, vol. 8, no. 1, pp. 95-102, 1998.

[44] T. Reya, A. W. Duncan, L. Ailles et al., "A role for Wnt signalling in self-renewal of haematopoietic stem cells," Nature, vol. 423, no. 6938, pp. 409-414, 2003.

[45] J. Antonchuk, G. Sauvageau, and R. K. Humphries, "HOXB4induced expansion of adult hematopoietic stem cells ex vivo," Cell, vol. 109, no. 1, pp. 39-45, 2002.

[46] N. H. Kim, H. S. Kim, N.-G. Kim et al., "p53 and MicroRNA34 are suppressors of canonical Wnt signaling," Science Signaling, vol. 4, no. 197, p. ra71, 2011.

[47] A. V. Molofsky, R. Pardal, and S. J. Morrison, "Diverse mechanisms regulate stem cell self-renewal," Current Opinion in Cell Biology, vol. 16, no. 6, pp. 700-707, 2004.

[48] I. Hofmann, E. H. Stover, D. E. Cullen et al., "Hedgehog signaling is dispensable for adult murine hematopoietic stem cell function and hematopoiesis," Cell Stem Cell, vol. 4, no. 6, pp. 559-567, 2009.

[49] J. Gao, S. Graves, U. Koch et al., "Hedgehog signaling is dispensable for adult hematopoietic stem cell function," Cell Stem Cell, vol. 4, no. 6, pp. 548-558, 2009.

[50] J. J. L. Jacobs and M. van Lohuizen, "Polycomb repression: from cellular memory to cellular proliferation and cancer," 
Biochimica et Biophysica Acta, vol. 1602, no. 2, pp. 151-161, 2002.

[51] T. Kajiume, Y. Ninomiya, H. Ishihara, R. Kanno, and M. Kanno, "Polycomb group gene mel-18 modulates the selfrenewal activity and cell cycle status of hematopoietic stem cells," Experimental Hematology, vol. 32, no. 6, pp. 571-578, 2004.

[52] H. Ohta, A. Sawada, J. Y. Kim et al., "Polycomb group gene rae28 is required for sustaining activity of hematopoietic stem cells," Journal of Experimental Medicine, vol. 195, no. 6, pp. 759-770, 2002.

[53] T. Yoshida, I. Hazan, J. Zhang et al., "The role of the chromatin remodeler Mi- $2 \beta$ in hematopoietic stem cell self-renewal and multilineage differentiation," Genes and Development, vol. 22, no. 9, pp. 1174-1189, 2008.

[54] C. J. Sherr and J. M. Roberts, "CDK inhibitors: positive and negative regulators of G1-phase progression," Genes and Development, vol. 13, no. 12, pp. 1501-1512, 1999.

[55] F. Bunz, A. Dutriaux, C. Lengauer et al., "Requirement for p53 and p21 to sustain $\mathrm{G}_{2}$ arrest after DNA damage," Science, vol. 282, no. 5393, pp. 1497-1501, 1998.

[56] T. Cheng, N. Rodrigues, H. Shen et al., "Hematopoietic stem cell quiescence maintained by $21^{\text {cip1/waf1 }, ~ S c i e n c e, ~ v o l . ~ 287, ~}$ no. 5459, pp. 1804-1809, 2000.

[57] R. van Os, L. M. Kamminga, A. Ausema et al., "A limited role for $\mathrm{p} 21^{\mathrm{cip} 1 / \text { Wafl }}$ in maintaining normal hematopoietic stem cell functioning," Stem Cells, vol. 25, no. 4, pp. 836-843, 2007.

[58] P. Zou, H. Yoshihara, K. Hosokawa et al., "p57 Kip2 and p27 Kip1 cooperate to maintain hematopoietic stem cell quiescence through interactions with Hsc70," Cell Stem Cell, vol. 9, no. 3, pp. 247-261, 2011.

[59] A. Matsumoto, S. Takeishi, T. Kanie et al., "p57 is required for quiescence and maintenance of adult hematopoietic stem cells," Cell Stem Cell, vol. 9, no. 3, pp. 262-271, 2011.

[60] Y. Yan, J. Frisén, M. H. Lee, J. Massagué, and M. Barbacid, "Ablation of the CDK inhibitor p57 ${ }^{\text {IIP2 }}$ results in increased apoptosis and delayed differentiation during mouse development," Genes and Development, vol. 11, no. 8, pp. 973-983, 1997.

[61] P. Zhang, N. J. Liégeois, C. Wong et al., "Altered cell differentiation and proliferation in mice lacking $\mathrm{p} 57^{K I P 2}$ indicates a role in Beckwith-Wiedemann syndrome," Nature, vol. 387, no. 6629, pp. 151-158, 1997.

[62] T. Cheng, N. Rodrigues, D. Dombkowski, S. Stier, and D. T. Scadden, "Stem cell repopulation efficiency but not pool size is governed by p27kipl," Nature Medicine, vol. 6, no. 11, pp. 1235-1240, 2000.

[63] R. M. Ko, H. G. Kim, L. Wolff, and C. A. Klug, "Roles of p $15^{\text {Ink4b }}$ and $p 16^{\text {Ink4a }}$ in myeloid differentiation and RUNX1ETO-associated acute myeloid leukemia," Leukemia Research, vol. 32, no. 7, pp. 1101-1111, 2008.

[64] B. J. Park, J. W. Kang, S. W. Lee et al., "The haploinsufficient tumor suppressor p18 upregulates $\mathrm{p} 53$ via interactions with ATM/ATR,” Cell, vol. 120, no. 2, pp. 209-221, 2005.

[65] L. Stepanova and B. P. Sorrentino, "A limited role for $\mathrm{p} 16^{\text {Ink4a }}$ and p19Arf in the loss of hematopoietic stem cells during proliferative stress," Blood, vol. 106, no. 3, pp. 827-832, 2005.

[66] Y. Yuan, H. Shen, D. S. Franklin, D. T. Scadden, and T. Cheng, "In vivo self-renewing divisions of haematopoietic stem cells are increased in the absence of the early G1-phase inhibitor, p18 ${ }^{\mathrm{INK} 4 \mathrm{C}}, "$ Nature Cell Biology, vol. 6, no. 5, pp. 436-442, 2004.

[67] K. Rinesh, Principles of Animal Cell Culture: Student Compendium, International Book Distributing, 2008.
[68] J. Campisi, "Cellular senescence as a tumor-suppressor mechanism," Trends in Cell Biology, vol. 11, no. 11, pp. S27S31, 2001.

[69] A. G. Bodnar, M. Ouellette, M. Frolkis et al., "Extension of life-span by introduction of telomerase into normal human cells," Science, vol. 279, no. 5349, pp. 349-352, 1998.

[70] C. B. Harley, A. B. Futcher, and C. W. Greider, "Telomeres shorten during ageing of human fibroblasts," Nature, vol. 345, no. 6274, pp. 458-460, 1990.

[71] A. R. Choudhury, Z. Ju, M. W. Djojosubroto et al., "Cdkn1a deletion improves stem cell function and lifespan of mice with dysfunctional telomeres without accelerating cancer formation," Nature Genetics, vol. 39, no. 1, pp. 99-105, 2007.

[72] K. L. Rudolph, S. Chang, H. W. Lee et al., "Longevity, stress response, and cancer in aging telomerase-deficient mice," Cell, vol. 96, no. 5, pp. 701-712, 1999.

[73] F. D’Adda Di Fagagna, P. M. Reaper, L. Clay-Farrace et al., "A DNA damage checkpoint response in telomere-initiated senescence," Nature, vol. 426, no. 6963, pp. 194-198, 2003.

[74] J. Karlseder, D. Broccoli, D. Yumin, S. Hardy, and T. De Lange, "p53- and ATM-dependent apoptosis induced by telomeres lacking TRF2," Science, vol. 283, no. 5406, pp. 1321-1325, 1999.

[75] S. D. Tyner, S. Venkatachalam, J. Choi et al., "p53 mutant mice that display early ageing-associated phenotypes," Nature, vol. 415, no. 6867, pp. 45-53, 2002.

[76] M. Dumble, L. Moore, S. M. Chambers et al., "The impact of altered p53 dosage on hematopoietic stem cell dynamics during aging," Blood, vol. 109, no. 4, pp. 1736-1742, 2007.

[77] U. Herbig, M. Ferreira, L. Condel, D. Carey, and J. M. Sedivy, "Cellular senescence in aging primates," Science, vol. 311, no. 5765, p. 1257, 2006.

[78] S. K. Singh, C. Hawkins, I. D. Clarke et al., "Identification of human brain tumour initiating cells," Nature, vol. 432, no. 7015, pp. 396-401, 2004.

[79] C. T. Jordan, M. L. Guzman, and M. Noble, "Cancer stem cells," The New England Journal of Medicine, vol. 355, no. 12, pp. 1253-1261, 2006.

[80] C. T. Jordan, "Cancer stem cell biology: from leukemia to solid tumors," Current Opinion in Cell Biology, vol. 16, no. 6, pp. 708-712, 2004.

[81] E. C. Buss and A. D. Ho, "Leukemia stem cells," International Journal of Cancer, vol. 129, no. 10, pp. 2328-2336, 2011.

[82] D. Bonnet and J. E. Dick, "Human acute myeloid leukemia is organized as a hierarchy that originates from a primitive hematopoietic cell," Nature Medicine, vol. 3, no. 7, pp. 730737, 1997.

[83] T. Lapidot, C. Sirard, J. Vormoor et al., "A cell initiating human acute myeloid leukaemia after transplantation into SCID mice," Nature, vol. 367, no. 6464, pp. 645-648, 1994.

[84] F. R. Appelbaum, J. M. Rowe, J. Radich, and J. E. Dick, "Acute myeloid leukemia," Hematology, pp. 62-86, 2001.

[85] C. T. Jordan, D. Upchurch, S. J. Szilvassy et al., "The interleukin-3 receptor alpha chain is a unique marker for human acute myelogenous leukemia stems cells," Leukemia, vol. 14, no. 10, pp. 1777-1784, 2000.

[86] U. Testa, R. Riccioni, S. Militi et al., "Elevated expression of IL-3R $\alpha$ in acute myelogenous leukemia is associated with enhanced blast proliferation, increased cellularity, and poor prognosis," Blood, vol. 100, no. 8, pp. 2980-2988, 2002.

[87] J. Lessard and G. Sauvageau, "Bmi-1 determines the proliferative capacity of normal and leukaemic stem cells," Nature, vol. 423, no. 6937, pp. 255-260, 2003. 
[88] A. Insinga, S. Monestiroli, S. Ronzoni et al., "Impairment of p53 acetylation, stability and function by an oncogenic transcription factor," The EMBO Journal, vol. 23, no. 5, pp. 1144-1154, 2004.

[89] A. Viale, F. De Franco, A. Orleth et al., "Cell-cycle restriction limits DNA damage and maintains self-renewal of leukaemia stem cells," Nature, vol. 457, no. 7225, pp. 51-56, 2009.

[90] D. S. Krause and R. A. Van Etten, "Right on target: eradicating leukemic stem cells," Trends in Molecular Medicine, vol. 13, no. 11, pp. 470-481, 2007.

[91] Y. Ben-Neriah, G. Q. Daley, and A. M. Mes-Masson, "The chronic myelogenous leukemia-specific P210 protein is the product of the bcr/abl hybrid gene," Science, vol. 233, no. 4760, pp. 212-214, 1986.

[92] E. Buchdunger, J. Zimmermann, H. Mett et al., "Inhibition of the Abl protein-tyrosine kinase in vitro and in vivo by a 2-phenylaminopyrimidine derivative," Cancer Research, vol. 56, no. 1, pp. 100-104, 1996.

[93] G. Q. Daley, R. A. Van Etten, and D. Baltimore, "Induction of chronic myelogenous leukemia in mice by the P210(bcr/abl) gene of the Philadelphia chromosome," Science, vol. 247, no. 4944, pp. 824-830, 1990.

[94] B. J. Druker, M. Talpaz, D. J. Resta et al., "Efficacy and safety of a specific inhibitor of the BCR-ABL tyrosine kinase in chronic myeloid leukemia," The New England Journal of Medicine, vol. 344, no. 14, pp. 1031-1037, 2001.

[95] M. E. Gorre, M. Mohammed, K. Ellwood et al., "Clinical resistance to STI-571 cancer therapy caused by BCR-ABL gene mutation or amplification," Science, vol. 293, no. 5531, pp. 876-880, 2001.

[96] S. M. Graham, H. G. Jørgensen, E. Allan et al., "Primitive, quiescent, Philadelphia-positive stem cells from patients with chronic myeloid leukemia are insensitive to STI571 in vitro," Blood, vol. 99, no. 1, pp. 319-325, 2002.

[97] N. Heisterkamp, K. Stam, and J. Groffen, "Structural organization of the bcr gene and its role in the Ph' translocation," Nature, vol. 315, no. 6022, pp. 758-761, 1985.

[98] P. le Coutre, E. Tassi, M. Varella-Garcia et al., "Induction of resistance to the Abelson inhibitor STI571 in human leukemic cells through gene amplification," Blood, vol. 95, no. 5, pp. 1758-1766, 2000.

[99] T. G. Lugo, A. M. Pendergast, A. J. Muller, and O. N. Witte, "Tyrosine kinase activity and transformation potency of bcrabl oncogene products," Science, vol. 247, no. 4946, pp. 10791082, 1990.

[100] F. X. Mahon, M. W. N. Deininger, B. Schultheis et al., "Selection and characterization of BCR-ABL positive cell lines with differential sensitivity to the tyrosine kinase inhibitor STI571: diverse mechanisms of resistance," Blood, vol. 96, no. 3, pp. 1070-1079, 2000.

[101] E. Shtivelman, B. Lifshitz, R. P. Gale, and E. Canaani, "Fused transcript of abl and bcr genes in chronic myelogenous leukaemia," Nature, vol. 315, no. 6020, pp. 550-554, 1985.

[102] E. Weisberg and J. D. Griffin, "Mechanism of resistance to the ABL tyrosine kinase inhibitor STI571 in BCR/ABLtransformed hematopoietic cell lines," Blood, vol. 95, no. 11, pp. 3498-3505, 2000.

[103] N. L. Komarova and D. Wodarz, "Effect of cellular quiescence on the success of targeted CML therapy," PLoS ONE, vol. 2, no. 10, article e990, 2007.

[104] K. N. Rice and C. H. M. Jamieson, "Molecular pathways to CML stem cells," International Journal of Hematology, vol. 91, no. 5, pp. 748-752, 2010.
[105] Y. Jiang, B. N. Jahagirdar, R. L. Reinhardt et al., "Pluripotency of mesenchymal stem cells derived from adult marrow," Nature, vol. 418, no. 6893, pp. 41-49, 2002.

[106] H. Nakajima, "Role of transcription factors in differentiation and reprogramming of hematopoietic cells," The Keio Journal of Medicine, vol. 60, no. 2, pp. 47-55, 2011.

[107] G. Ferrari, G. Cusella-De Angelis, M. Coletta et al., "Muscle regeneration by bone marrow-derived myogenic progenitors," Science, vol. 279, no. 5356, pp. 1528-1530, 1998.

[108] R. E. Bittner, C. Schöfer, K. Weipoltshammer et al., "Recruitment of bone-marrow-derived cells by skeletal and cardiac muscle in adult dystrophic mdx mice," Anatomy and Embryology, vol. 199, no. 5, pp. 391-396, 1999.

[109] D. Orlic, J. Kajstura, S. Chimenti et al., "Bone marrow cells regenerate infarcted myocardium," Nature, vol. 410, no. 6829, pp. 701-705, 2001.

[110] E. Lagasse, H. Connors, M. Al-Dhalimy et al., "Purified hematopoietic stem cells can differentiate into hepatocytes in vivo," Nature Medicine, vol. 6, no. 11, pp. 1229-1234, 2000.

[111] B. E. Petersen, W. C. Bowen, K. D. Patrene et al., "Bone marrow as a potential source of hepatic oval cells," Science, vol. 284, no. 5417, pp. 1168-1170, 1999.

[112] N. D. Theise, S. Badve, R. Saxena et al., "Derivation of hepatocytes from bone marrow cells in mice after radiationinduced myeloablation," Hepatology, vol. 31, no. 1, pp. 235240, 2000.

[113] N. D. Theise, M. Nimmakayalu, R. Gardner et al., "Liver from bone marrow in humans," Hepatology, vol. 32, no. 1, pp. 11$16,2000$.

[114] M. R. Alison, R. Poulsom, R. Jeffery et al., "Hepatocytes from non-hepatic adult stem cells," Nature, vol. 406, no. 6793, p. 257, 2000.

[115] Y. Lin, D. J. Weisdorf, A. Solovey, and R. P. Hebbel, "Origins of circulating endothelial cells and endothelial outgrowth from blood," Journal of Clinical Investigation, vol. 105, no. 1, pp. 71-77, 2000.

[116] T. Asahara, H. Masuda, T. Takahashi et al., "Bone marrow origin of endothelial progenitor cells responsible for postnatal vasculogenesis in physiological and pathological neovascularization," Circulation Research, vol. 85, no. 3, pp. 221-228, 1999.

[117] D. S. Krause, N. D. Theise, M. I. Collector et al., "Multiorgan, multi-lineage engraftment by a single bone marrowderived stem cell," Cell, vol. 105, no. 3, pp. 369-377, 2001.

[118] H. Hong, K. Takahashi, T. Ichisaka et al., "Suppression of induced pluripotent stem cell generation by the p53-p21 pathway," Nature, vol. 460, no. 7259, pp. 1132-1135, 2009. 

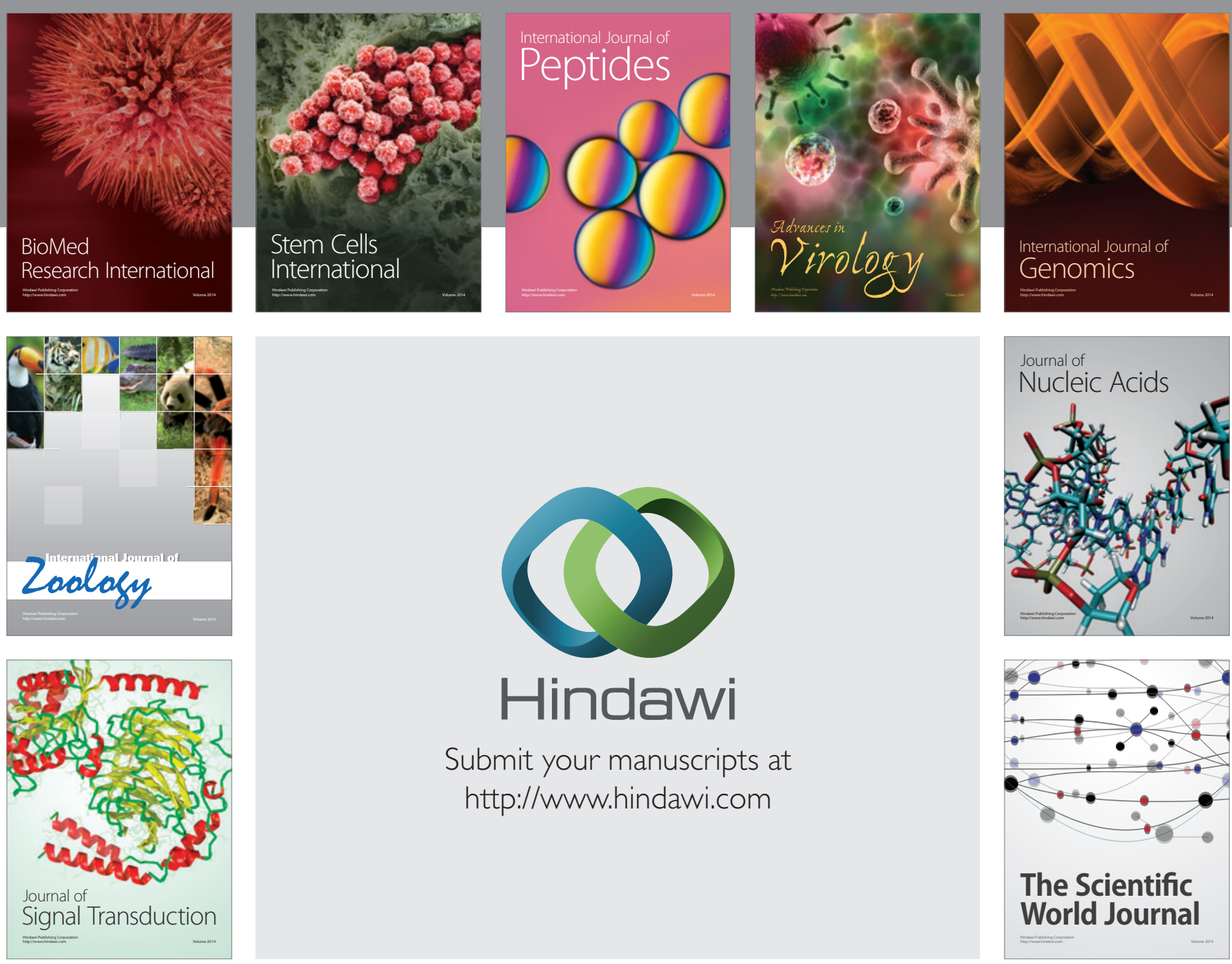

Submit your manuscripts at

http://www.hindawi.com
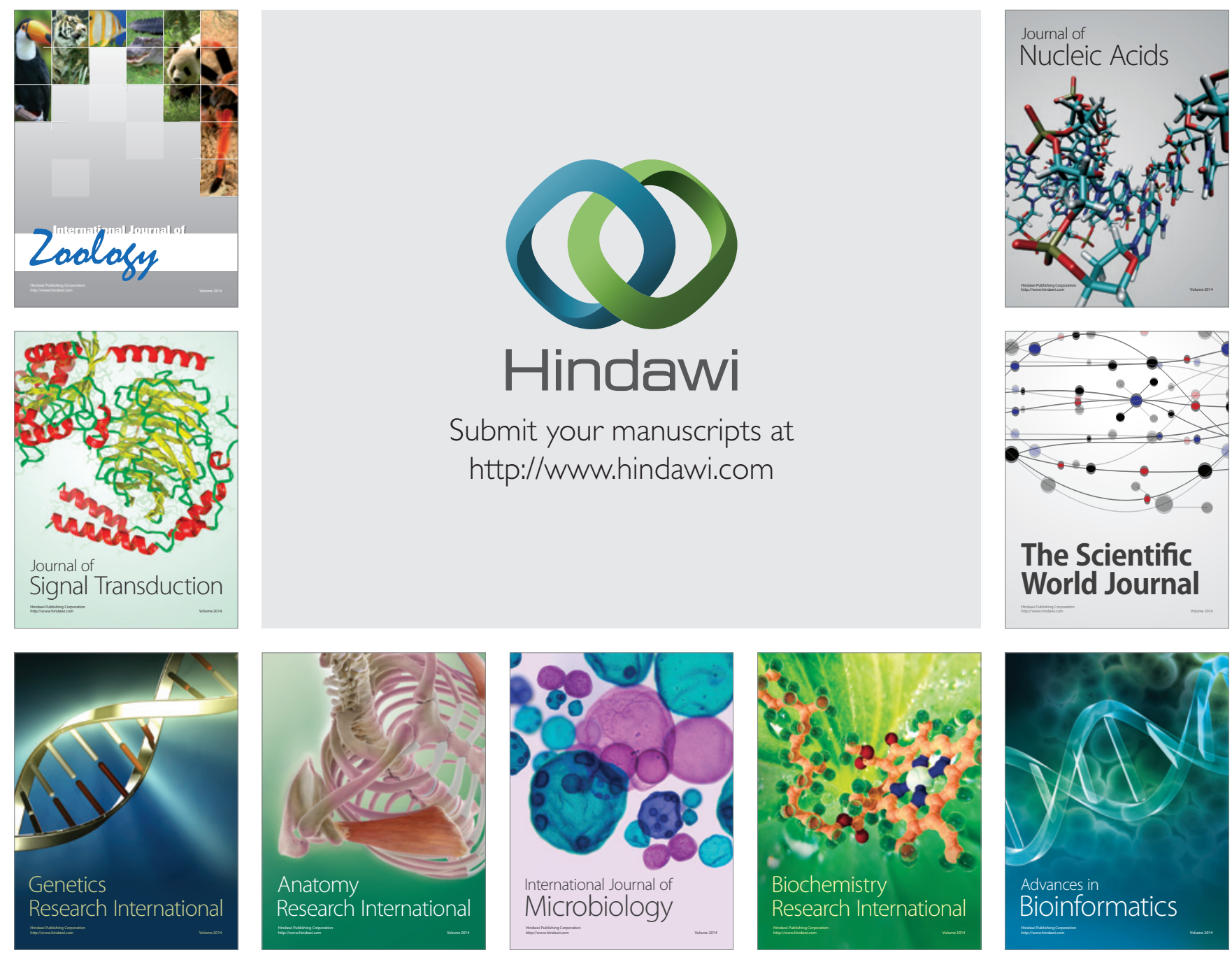

The Scientific World Journal
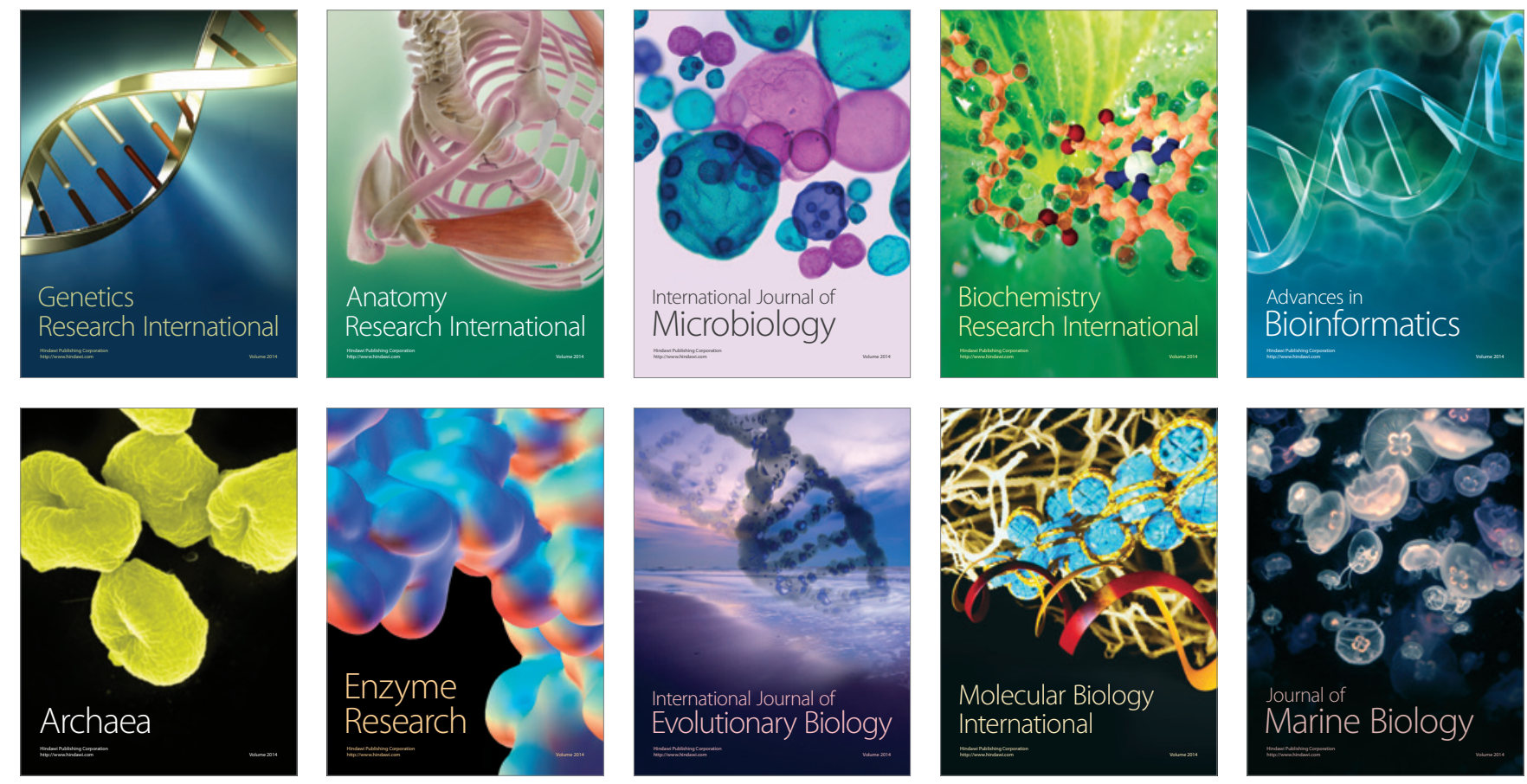